\title{
独自の顧客接点を活用した 信頼のブランドづくり
}

一株式会社ファンデリー -

学習院大学大学院 経営学研究科 研究生

中津 光広
学習院大学 経済学部 経営学科 教授

青木 幸弘

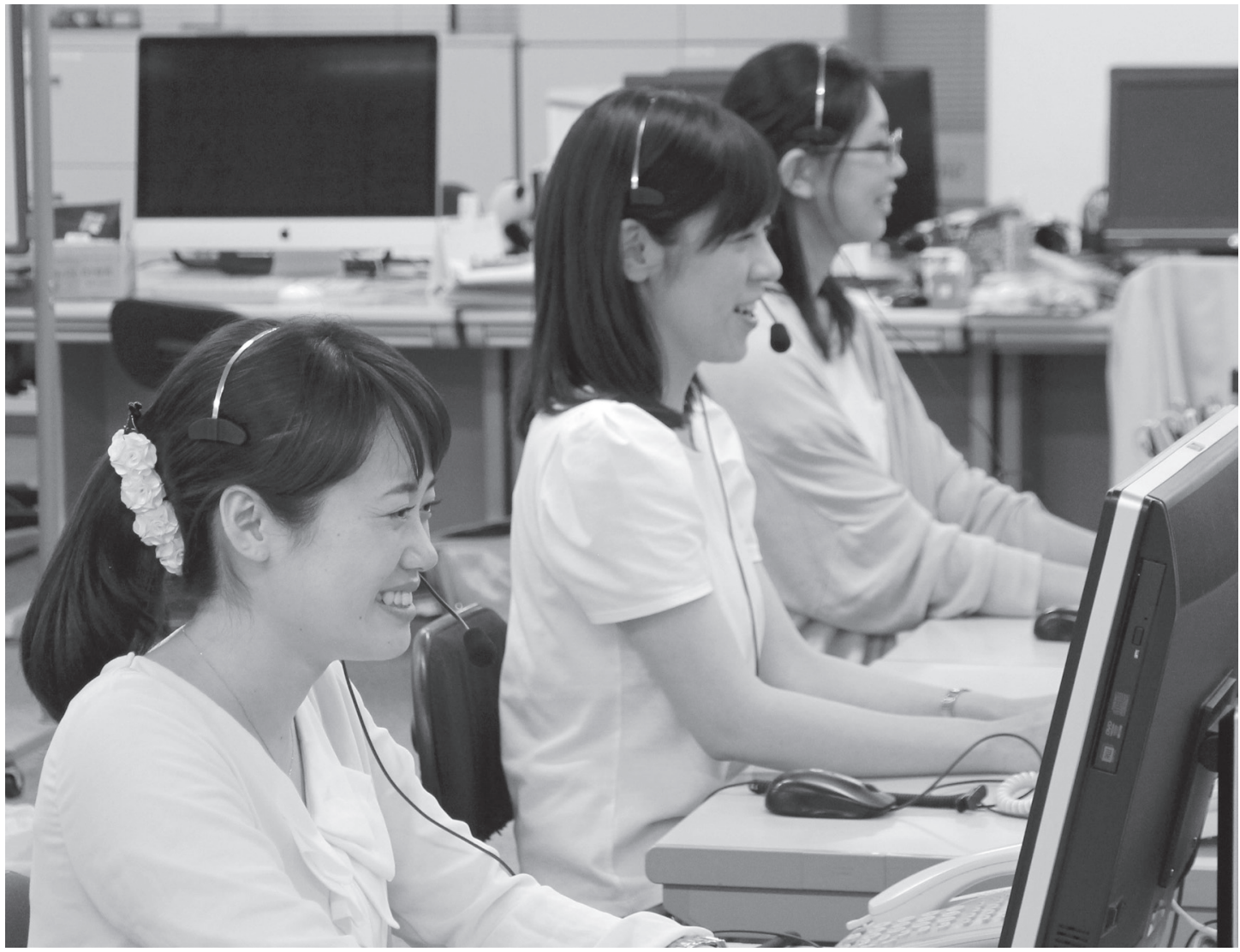

顧客からの電話に対応する管理栄養士の社員 


\section{I . はじめに}

「主食太りからアナタを守る!」「美味しい食 事をお手軽に!ヘルシーに!」「健康で美味しく て続けられる」これらの宣伝文句は, 健康食品, 宅配食の通販を行っている企業で実際に使われ ているキャッチコピーである。消費者の健康に 対する信仰心を上手く刺激することで，健康管 理や健康維持のための商品やサービスを扱う健 康産業は花盛りだ。勿論, ただの健康ブームと いう一過性のものではなく, その背景として生 活習慣病を患う人の増加を指摘することが出来 $ろ^{1)}$ 。

この生活習慣病の代表例である糖尿病が，世 界的に急増しているという ${ }^{2)}$ 。実際に我が国の 糖尿病者数はどれくらいなのであろうか? 厚生 労働省が2012年に行った「国民健康·栄養調査」 によると，2012年 10 月時点で 2,050 万人もの人 が糖尿病者とみなされている。なんとこれは日 本人全体の $16.3 \%$ にもたる。

糖尿病の治療には, 薬物療法, 運動療法, 食 事療法がある。中でも食事療法は, 糖尿病治療 の基本といわれている。よって糖尿病患者は, 日々の食生活の中で，カロリー，塩分，たんぱ く質，脂質などの摂取量をそれぞれ細かく制限 されてしまう。たいていの患者は，医師らの栄 養指導を基にして, 自己流の食生活改善を行っ ていく。しかし多くの場合, 栄養価の管理が如 何に難しく，面倒なことかを思い知らさせられ る。その結果, 食事のコントロールは御座なり になり，血液検查などの数值改善は見込めない のである。

このように糖尿病など生活習慣病を患う人た
ちは，日々の食生活において栄養価の管理で悩 まされている。この食事のコントロールにかか る手間を代わりに引き受け，徹底的にサポート し成長している企業が，本稿で取り上げる株式 会社ファンデリー（以下，「ファンデリー」）で ある。

同社のビジネス・モデルの特徵は, 疾病ごと に栄養価を調整した食事を冷凍状態で宅配する と共に，血液検查などの数值改善を顧客と同社 の栄養士が二人三脚で行っている点にある。自 社のリソースである栄養士を最大限に活用し, 独自の顧客接点づくりを行なってきた同社の足 跡をたどりながら，信頼のブランドづくりにつ いて考えていきたい。

\section{II . ファンデリーの概要}

株式会社ファンデリーは，東京都北区に本社 を置き，健康食の宅配サービスを行っている。 2000 年 9 月に, 同社代表取締役の阿部公祐氏に より設立された（図表-I）。社名は，FUN（面 白さ・楽しさ・感動) とDELIVERY (お届けする) という $2 つ の$ 単語の組み合わせに由来する。社 会に感動を届け多くの人々を幸せにする企業で ありたいという願いを込めて命名したという。

ファンデリーでは, 多くの人が心身の健康 （ウェルネス）を得て，高齢になっても元気に就 労できるような社会環境を理想としている。阿 部社長は，豊かな未来社会を作るためには医療 費を削減するための取り組みが必要だと考え ${ }^{3)}$, 「一食二医」社会の実現を大義として掲げてい る。健康管理には，第一に日々の「食事のコン トロール」が必要になる。それでも困難な場合 に「医療」に頼る。このような意味が「一食二医」 


\begin{tabular}{|c|c|}
\hline 2000年 9月 & 東京都北区赤羽西に株式会社ファンデリ一を設立 \\
\hline 2001年 4月 & 栄養士による宅配サービス、『カウンセリングデリバリー』をスタート \\
\hline 7月 & 食材の宅配サービスを開始 \\
\hline 2004年 3月 & 東京都北区赤羽一丁目に本社を移転 \\
\hline 4月 & 健康食通販カタログ『ミールタイム』を創刊 \\
\hline 2005年 4月 & 『ミールタイム』の発行を年2回に変更 \\
\hline 2008年10月 & 管理栄養士・栄養士コミュニティサイト『Foodish』を開設 \\
\hline 2009年10月 & 『ミールタイム ファーマ』と『ミールタイム ケア』創刊 \\
\hline 2011年 4月 & カウンセリングデリバリー事業の展開を目的に、当社の100\%会社として埼玉県川口市に株式会社カウンセリングデリバリーを設立 \\
\hline 10月 & 『ミールタイム ケア』を『ミールタイム』に統合し、発行を年4回に変更 \\
\hline 10月 & ミールタイム定期コ一スを「栄養士おまかせ定期便」に名称変更 \\
\hline 14 年 1 日 & 株式会社カウンセリングデリバリ一を吸収合併 \\
\hline
\end{tabular}

という言葉に込められている。この第一の「食」 の分野で貢献するのが栄養士であり，栄養士の 活躍はファンデリーの大きな資産となっている

事業内容は, マーケティング事業と MFD (Medical Food Delivery) 事業の2つに大別さ れる。マーケティング事業では, 顧客企業（食 品メーカー, 健康家電メーカー, 製薬メーカー) へのマーケティング提案と, 2015年 3 月末現在 で 4 万 3,000 人のネットワークがある管理栄養 士・栄養士向けコミュニティサイト『Foodish (フーディッシュ)』の運営を行っている。 MFD 事業では, 慢性疾患者を対象に食事のコ ントロールを通して血液検查結果の数值改善を 目指す健康食の宅配サービス『ミールタイム』 と, 通販サイト『ミールタイム』を運営している。
2015 年 3 月期の売上高は 26 億 6,850 万円, 経常 利益は 4 億 3,747 万円, 経常利益率は $16.4 \%$ であ る(図表-2)。従業員数は 2015 年 3 月末現在 41 名で, その内 28 名が管理栄養士， 4 名が栄養士 となっている（図表-3）（尚，同社は 2015 年 6 月 25 日に東京証券取引所マザーズ市場に上場 予定である)。

2001年 4 月に日本初の栄養士による宅配サー ビス『カウンセリングデリバリー』を開始した。 これは, 栄養士が顧客の自宅まで車で直接商品 を届け, カウンセリングを行うサービスである。 そして 2004 年 4 月に健康食通販カタログ『ミー ルタイム』, 2009 年 10 月には『ミールタイム ファーマ』を創刊した。これらは, 通販で商品 を届けるスタイルとなる。創業時は, カウンセ

\section{図表—2 ファンデリーの会社概要}

\begin{tabular}{|l||c|}
\hline 会社名 & 株式会社ファンデリ一 \\
\hline 代表者 & 代表取締役 阿部公祐 \\
\hline 設立 & 2000年9月 \\
\hline 資本金 & 1 億6,545万円 \\
\hline 売上高 & 26 億6,850万円 \\
\hline 経常利益 & 4 億3,747万円 \\
\hline 経常利益率 & $16.4 \%$ \\
\hline 事業内容 & MFD (Medical Food Delivery) 事業 \\
マーケティング事業
\end{tabular}




\begin{tabular}{|l|c|c|}
\hline & 従業員数 & 内訳 \\
\hline \hline MFD事業 & 28名 & 管理栄養士25名、栄養士3名 \\
\hline マーケテイング事業 & 3名 & 管理養士2名、栄養士1名 \\
\hline その他 & 10 名 & 管理栄養士1名、他9名 \\
\hline 合計 & 41 名 & \\
\hline
\end{tabular}

リングデリバリーがメインであったが，現在は 通販スタイルの『ミールタイム』がメインとなっ ている（図表-4）。

『ミールタイム』のカタログは 3 カ月に 1 度発 行しており, 発行部数は 2015 年 3 月 1 日発行の ものから 75 万部 (年間 300 万部) となる。『ミー ルタイムファーマ』のカタログは 6 カ月に 1 度 の発行で 25 万部（年間 50 万部）となっている。 『ミールタイム』は，2015年 3 月末現在，全国 約 1 万 3,800 か所の医療機関等に, 『ミールタイ ムファーマ』は, 全国約 4,000か所の調剂薬局
にそれぞれ置かれている。

これらのカタログを医療機関に置く理由は, 血液検査デー夕や食事制限に合わせた食事療法 を必要としている患者さんのために，専門家が アドバイスを行い手渡しするという形を取るた めだ。さらに，このカタログによって注文を受 けた際に，ファンデリーの栄養士によるカウン セリングをセットで行う。このカウンセリング によって顧客一人一人の症状に合わせた健康食 の提案・販売をしている。

注文された商品は, 外部委託した工場で作ら 図表—4ファンデリーの事業系統図

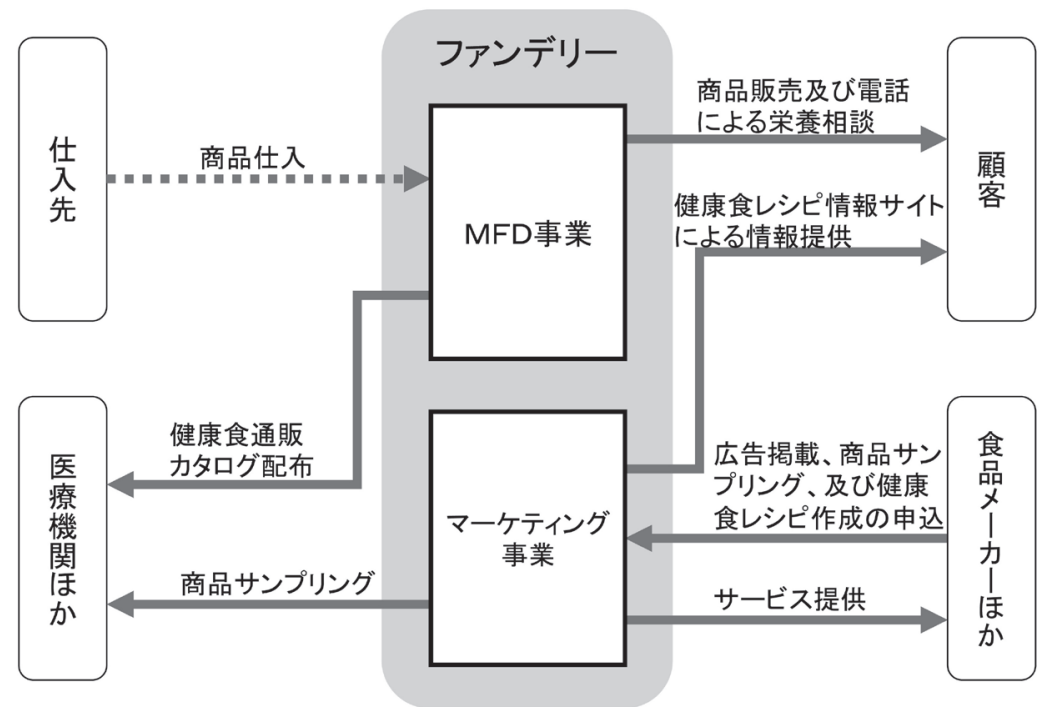


れて,ヤマト運輸を利用して顧客に届けられる。 冷凍状態で宅配されるので, 電子レンジで温め ればすぐに食べることが出来る。食習慣による 健康改善は, 薬のように短期間で劇的な効果を 現すものではない。そのため, 健康食としての 効果を出すために, 注文は7食以上から受け付 けている。

商品である健康食には，おかずのみのタイプ とご飯が付いたタイプがある。価格は 1 食 400 円台後半から 600 円台内で設定されている。大 手中食業や他の宅配食と比べて同程度の価格, コンビニ弁当と比べると若干割高とみてよいで あろう。

商品となる健康食は, (1)へルシー食, (2)へル シー食多め, (3)たんぱく質調整食, (4)ケア食, の 4 種類である（図表-5）。

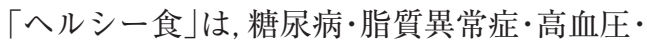
痛風の疾患を伴った，太り気味でカロリーや塩 分を制限した健康的な食事を取りたい者をター ゲットとしている。「ヘルシー食多め」は，へ ルシー食と同様にカロリーや塩分を調整した内
容となっているが，ヘルシー食では量が少し物 足りないと感じる人向けに作られた。「たんぱ く質調整食」は腎臓病の疾患者をターゲットに, たんぱく質・カリウム・リン・塩分を控えた内 容となっている。「ケア食」は，カロリーや塩 分のコントロールだけではなく, 咀嚼力の弱い 人であったり，繊維質が苦手な人向けである。

以上のように, 提供されている健康食は, 顧 客の健康状態・疾患の症状・加齢に応じて選択 しやすいように工夫されており，ファンデリー は，ミールタイムをメデイカル的なソリュー ションビジネスとして位置付けているのであ る。

次節では宅配食市場の現状を理解するため に，少し俯瞰して中食市場から見ていこう。

\section{III. 中食市場における宅配食の位置づけ}

外食市場の成長が停滞している中でも「食」 の外部化は進展している。その背景としては, 高齢化社会の進展による 1 人あたりの食料需要 図表—5 メニューカテゴリー

\begin{tabular}{|c|c|c|c|c|}
\hline & ヘルシー食 & ヘルシー食多め & たんぱく質調整食 & ケア食 \\
\hline 主な特徵 & \multicolumn{2}{|c|}{ カロリー・塩分の制限 } & $\begin{array}{c}\text { たんぱく質· } \\
\text { カリウム・ } \\
\text { リンの制限 }\end{array}$ & やわらかい \\
\hline \multirow[t]{2}{*}{ 商品例(※) } & $\frac{3}{4 x}$ & & & \\
\hline & $\begin{array}{c}\text { だし巻き卵の } \\
\text { カニあんセット } \\
\text { 598円 }\end{array}$ & $\begin{array}{c}\text { ハンバーグの } \\
\text { 照焼きソースセット } \\
\text { 698円 }\end{array}$ & $\begin{array}{c}\text { トンカツセット } \\
\text { 598円 }\end{array}$ & $\begin{array}{l}\text { 骨なし鯖の } \\
\text { 味噌煮セット } \\
\text { 598円 }\end{array}$ \\
\hline
\end{tabular}

（※）2015春号カタログにおける商品・サービス内容 
量の減少や，少子化・核家族化による単身世帯・ 夫婦のみ世帯の増加といった世帯構造の変化, （特に既婚）女性の就業率上昇による家事時間 の短縮などが考えられる。この「食」の外部化 を追い風に，緩やかではあるが依然として中食 市場は成長を続けている

公益財団法人食の安全・安心財団によると 2011 年の市場規模は外食 23 兆円，中食 5 兆 7 千億円である。中食は，上記の要因を背景とし て, 経済性・簡便性・時間の節約という点で外 食内食より優位性があるので，今後も成長が続 くと考えられる（図表-6）。

この中食市場の拡大基調は，中食企業の事業 強化だけではなく，他分野の企業による新規参 入も促している。例えば， ワタミは 2008 年に 外食事業で培ったノウハウを活用して高齢者向 けに扮弁当の提供を開始した。加えて，コンビ ニ最大手のセブンイレブンは，2006年3月にお
弁当や抄菜を宅配するサービス「セブンミー ル」を首都圈から全国へと拡大をしている。さ らに，外食の定食屋チェーン店大戸屋は，2005 年にお弁当・お惣菜・オードブルを取り扱う店 舗展開を始めた。

近年では中食業の中でも特に「宅配食」サー ビスに関心が集まり始めている ${ }^{6)}$ 。矢野経済研 究所が行った「食品宅配市場に関する調查結果 2013」によると,ここで食品の宅配市場規模は, 2012 年で 1 兆 8,078 億円であり，2017年には 2 兆 2 千億円となると予測している。食品の宅配 市場とは, (1)在宅配食サービス, (2)惣菜宅配サー ビス，(3)宅配ピザ，(4)宅配寿司，(5)外食チェー ン・ファストフードの宅配，6牛乳宅配，(7)生 協の個配サービス，8音ットスーパー宅配，(9) コンビニエンスストア宅配, 10自然派食品宅配, が対象となる（図表-7）。

食品宅配の提供スタイルは大別すると2つで 図表—6 外食・中食産業の市場規模の推移（単位：兆円）

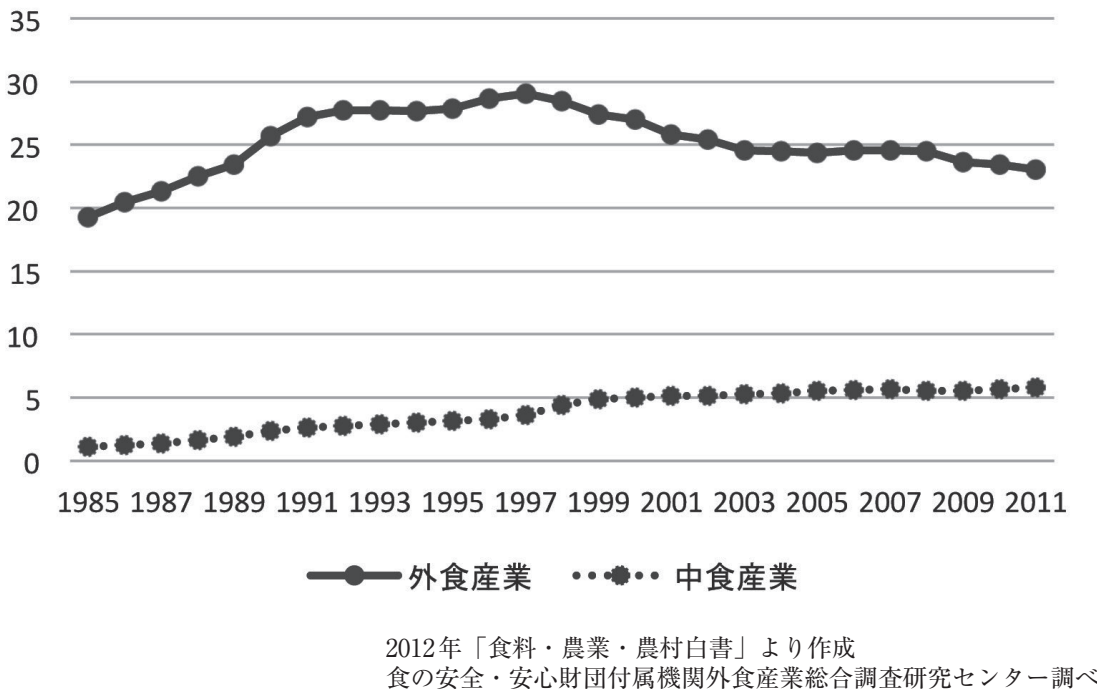




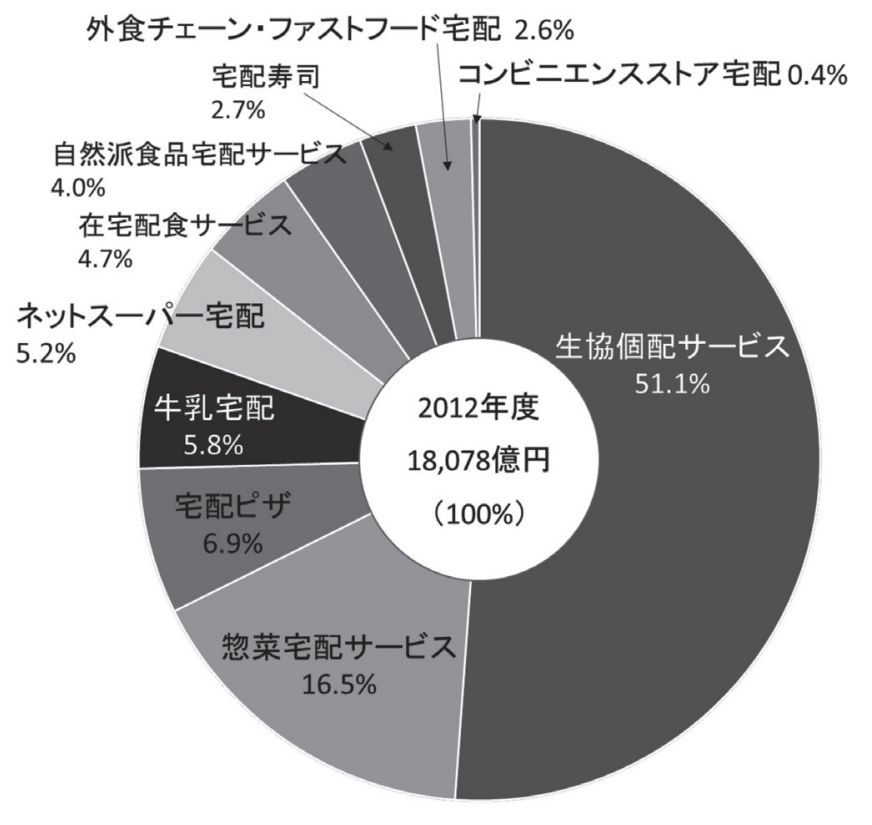

矢野経済研究所「食品宅配市場に関する調查結果 2013」

ある。すなわち，使い切りできる量や，調理の 手間を省いたカット済みの生鮮食品・野菜を提 供する「食材系」と，調理盛りつけ済みの书弁 当・お惣菜等を常温・保温・保冷・冷凍で提供 する「お弁当系」である（図表-8）。

本稿での対象となる「宅配食」とは，お弁当 系の「(1)在宅配食サービス」と「(2)惣菜宅配サー ビス」を指す。もともと，お弁当や扮惣菜の在
宅配食サービスは，自治体に委託されたNPO や地場の弁当事業者が高齢者や要介護者向けに 手掛ける社会福祉事業の1つという趣が強かっ た。主に，家族の支援等が期待できなく，食事 の支度が困難な単身または夫婦のみの高齢者宅 にお弁当や㧾菜を届け，その配達を通じて利 用者の安否確認を行っていた。その後, 介護保 険料の増大に伴い公的な配食サービスの縮小傾

\section{図表—8 食品宅配の提供スタイル（括弧内はその代表的な企業）}

\begin{tabular}{|l|l|}
\hline \multicolumn{1}{|c|}{ 食材系 } & \multicolumn{1}{c|}{ お弁当系 } \\
\hline \hline 生協の個配サービス(コープ) & 惣菜宅配サービス(ベルーナ、ニチレイフーズ) \\
\hline 牛乳宅配(森永乳業、雪印、小岩井乳業) & 宅配ピザ(ピザハット、ドミノピザ、ピザーラ) \\
ネットスーパー宅配(イオン、SEIYU) & 在宅配食サービス(ワタミ、日清医療食品) \\
自然派食品宅配(Oisix、パルシステム) & 宅配寿司(銀のさら、がってん寿司) \\
\hline & 外食チェーン・ファストフード宅配(ガスト、マクドナルド) \\
& コンビニエンスストア宅配(セブンイレブン、ローソン) \\
\hline
\end{tabular}


向が指摘され始め, 安否確認義務の撤廃などに より敷居が低くなると民間事業者の参入が増え た。その結果，主として高齢者を中心に考えら れてきた「宅配食」の市場に，「健康食」「治療 食」といわれるような健康管理を目的としてい る人向けの新たな領域が誕生したのである。

現在では，糖尿病や高血圧，腎臓病など食事 の管理が必要な人に向けて，栄養士がその疾病 に適したメニューを考案し，お弁当を届ける サービスが展開されている。従来の宅配食サー ビスよりも明確にターゲットが絞られており, 生活習慣病の予防という点から長期間にわたっ
て利用してもらえるサービスとなった。

このように「健康食」「治療食」の宅配とい う新たな市場が生まれた理由としては，健康管 理に関心の高い潜在顧客の存在が挙げられる。

\section{IV. 健康食の宅配ビジネスが注目される背景}

厚生労働省が 2013 年に行った「国民健康・ 栄養調査」調査によると, BMI (Body Mass Index：人の肥満度を表す体格指数）において, 男性は $28.6 \%$ ，女性は $20.3 \%$ が肥満であるとの 報告されている（図表-9）。BMIによる肥満者

図表—9 BMIの範囲別人数の割合

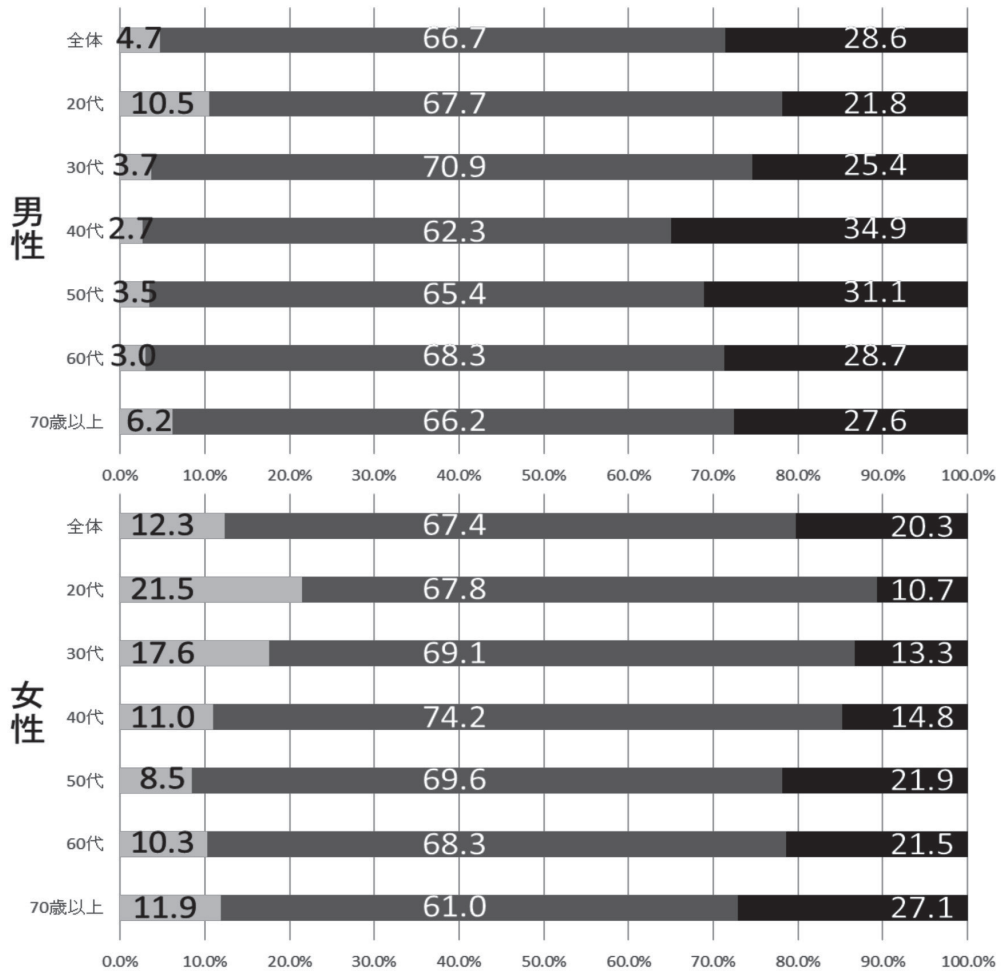

2013年「国民健康・栄養調查結果の概要」4頁 
数は，女性と比べて男性の方が多いので，肥満 については明らかに女性より男性に問題が大き いことが分かる。さらに詳しく男性肥満者の割 合を年代別に見てみると，20代で $21.8 \% ， 30$ 代 で $25.4 \% ， 40$ 代で $34.9 \% ， 50$ 代で $31.1 \% ， 60$ 代 で28.7\%，70歳以上で $27.6 \%$ という結果である。 男性の 40,50 代は 3 人に 1 人が肥満者というこ とになる。

では，実際に体重管理を行っている人はどの くらいいるのであろうか? 厚生労働省が 2004 年に行った「国民健康・栄養調査」調査による と，男女ともに年齢が高くなるほど体重コント ロールを心がけている人の割合が増える傾向 にある。男性を年代別に見てみると，20代で $54.1 \% ， 30$ 代で $52.5 \% ， 40$ 代で $57.1 \% ， 50$ 代で $59.4 \% ， 60$ 代で $72.4 \% ， 70$ 歳以上で $64.6 \%$ とい う結果になっている。20歳以上の男性において, 約 6 割の人が体重管理を実践しているにもかか わらず，約 3 割が肥満者ということになる（図 表-10)。

この肥満が原因となって, メタボリックシン ドロームといわれる糖尿病・脂質異常症・高血 圧・痛風などの合併症を引き起こす。これらを 放っておくと, 腎臟病・糖尿病性腎症・透析へ とつながり，最終的には狭心症や心筋梗塞に 至ってしまう。また，数值で表わされるような BMIによる肥満とは診断されなかったとして も, 内蔵脂肪が蓄積するタイプのような, いわ
ゆる「隠れ肥満者」においても，BMI肥満者 と同様に糖尿病・脂質異常症・高血圧などの生 活習慣病を引き起こしやすくなる。

食べ過ぎ・飲み過ぎ・欠食などの乱れた食生 活は, 内臓脂肪を増やす要因だ。健康的な生活 を送るためには，栄養バランスの良い食事を適 切に取ることによって, 内臓脂肪をコントロー ルする必要がある。このためには，摂取エネル ギー量（合計カロリー）に関心を払わなければ ならない。加えて，各栄養素の必要量をきちん と確保することが重要となる。

しかし, 日々忙しい現代人には, 毎日規則正 しい3食を実践することは非常に難しい。加え て，食による栄養バランスをどのように改善し ていけばよいのかが分からない人は多いことで あろう。このため食生活改善を目的として，ダ イエット効果や栄養バランスを謳った料理レシ ピ本やテレビの料理番組や, 昨今話題となった タニタ食堂や病院内レストランの美味しい健康 食などが注目を集めた。健康食の宅配サービス は，このような食による健康改善に関心の高い 潜在顧客に対して，自分で管理するとなると大 変な食生活をサポートしていこうというべネ フィットの提案になっている。

\section{V. 宅配食サービスのコモディティ化}

このような背景を理由に注目を集める「健康

図表—10 体重コントロールを実践する人の割合

\begin{tabular}{|c|c|c|c|c|c|c|c|c||c|}
\hline & 全年齢 & $15 \sim 19$ 歳 & $20 \sim 29$ 歳 & $30 \sim 39$ 歳 & $40 \sim 49$ 歳 & $50 \sim 59$ 歳 & $60 \sim 69$ 歳 & 70歳以上 & 20歳以上 \\
\hline 全体 & $64.9 \%$ & $53.0 \%$ & $61.3 \%$ & $60.4 \%$ & $62.6 \%$ & $67.4 \%$ & $74.8 \%$ & $64.2 \%$ & $65.7 \%$ \\
\hline \hline 男性 & $59.6 \%$ & $44.7 \%$ & $54.1 \%$ & $52.5 \%$ & $57.1 \%$ & $59.4 \%$ & $72.4 \%$ & $64.6 \%$ & $60.8 \%$ \\
\hline 女性 & $69.5 \%$ & $62.6 \%$ & $67.2 \%$ & $67.3 \%$ & $67.4 \%$ & $74.6 \%$ & $76.9 \%$ & $63.8 \%$ & $69.8 \%$ \\
\hline
\end{tabular}

2004 年「国民健康・栄養調查」186頁 
食」「治療食」の宅配食市場であるが，既に成 熟市場の様相も呈し始めている7)。現在では, 糖尿病・腎臓病・高血圧・メ夕ボ対策などの生 活習慣病のための食事療法を訴求する事業者を 数多く見つけることが出来る。

栄養バランス, 美味しさや豊富なメニュー, 食品の衛生・安全管理体制, 湯煎や電子レンジ でチンするだけの手軽さ，即日配達，などを訴 え，他社との差別化を試みようとしている事が 伺える。それらの具体的な内容を見てみると， 栄養バランスでは, 栄養士による献立作りや品 目数の配慮など，衛生・安全管理体制では，ス タッフの衛生管理や食中毒防止のマニュアル作 成・提示に取り組んでいる。

しかし結局，これらの取組は，後発の企業で も真似が出来てしまう取り組みである。その結 果, 明確な差別化を打ち出せず，健康食の宅配 サービスではコモディティ化が進んでいる。コ モディティ化により，各事業者が提供する健康 食宅配サービスに本質的な違いがそしくなる と，最終的にはどうしても価格を軸とした競争 に陥りやすくなる。よって, 商品やサービスの 提供方法という面だけではない差別化や強みの 形成が必要となる。

この点で「ファンデリー」は, 自社の栄養士 というリソースを上手く活用して信頼性を醸成 し，この信頼性を強みとして顧客の獲得と維持 に成功しているのである。

\section{VI.『ミールタイム』の着想とその取り組み}

ファンデリーの宅配食サービスは, 当初, 夕 食の材料を家庭に届けるスタイルである「食材 系」の宅配から始まった。
共働き世帯の増加により, 家族がバラバラで 食事をする機会が増えていることに着目したと いう。手間を省いて簡単に調理することができ, かつ，その食材で作った料理によって食事のコ ントロールができるようにしていた。

そんな中のある日，糖尿病を患った顧客の中 から, 糖尿病や腎臓病の疾患者向けに適した食 事を作って欲しいとの声が届いた。基本的に低 カロリーや塩分控えめの食事は，食で健康管理 を行おうとしている人全員に関係がある。しか し，食事でコントロールしたい人向けというあ る意味漠然としていた健康食を, ある程度その 対象を明確にしてみようと思い立った。糖尿病 食・脂質異常食・痛風食といった具合に, それ ぞれの疾病に適した食事を作っていこうと考え たのである。

当時は, 糖尿病食・脂質異常食というように 疾病ごとにターゲットを狭めていくことはニッ チなイメージが強かった。しかし, 疾病構造が 日々の生活習慣から起こる慢性疾患系の基調に ある点や，実際に糖尿病や腎臓病で困っている 人が増えている点を考慮し, 社会貢献という意 味も达めて, 徐々に「食材系」の宅配食サービ スから，それぞれの疾病に適した健康維持・数 值改善のための「抬弁当系」の宅配サービスへ と移行していく。

新規の顧客を獲得するために，初めはポス ティングや新聞折り込み等を活用して広告活動 を行った。しかし, 広告費をかけて顧客獲得と 利益確保を両立することの難しさを感じ，広告 にはあまり費用をかけずに顧客を獲得していく 方法を模索することになる。そこで考えたのが, カタログという形式であった。商品となる健康 食のカタログに, 読み物となる食にまつわる健 
康管理についてのコンテンッと, 食や健康に携 わる企業の広告を載せた（図表-II）。読み物の 主な内容は，今では人気コンテンツとなった四 季折々の敃锥め料理レシピ「おいしい四季のレ シピ」，様々な企業の食品を集め栄養価を表示 した「カロリーマップ」, 顧客の声を届けた「イ ンタビュー記事」などを載せている（図表-12, 13）。読み物としてのコンテンツが先にあって, カタログの製作経費を下げるために広告をとい う着想である。

一番最初のカタログは当然見本となるモノが ないので，広告を載せてくれる企業を得ること が非常に苦労したという。当時はまだ医療機関 のネットワークもなく, 社員数も少なかったの で，とにかくたくさんの企業にアプローチし提 案を行った。結果，応援票という意味合いが強 かったのかもしれないが, ファンデリーの考え
に賛同してくれた企業の協力を得ることが出来 た。1号目のカタログには, サントリー, アボッ トジャパン, エスビー食品, タニタ, バクスター, 日本水産, ブルドックソースなどの企業が広告 揭載している。阿部社長が当時を振り返り「まあ 〜ホントによく（広告を）取れたなと思います ね」と語るほどメジャーな企業が参加してくれ たのである。

メジャーな企業が 1 号目のカタログに参加し てくれたことは，2号目 3 号目へと広告を得る ために, 新たな参加企業への安心感に繋がった。 さらに，これは単にカタログ製作コストのため の広告費削減という問題だけではない。ファン デリーの考えに共鳴してくれたメジャーな企業 がカタログに登場することによって，そのカタ ログを読む読者への信頼度も高まるのである。 現在では多くの企業の賛同を得て, カタログ製

\section{図表—ー『ミールタイム』の紹介}

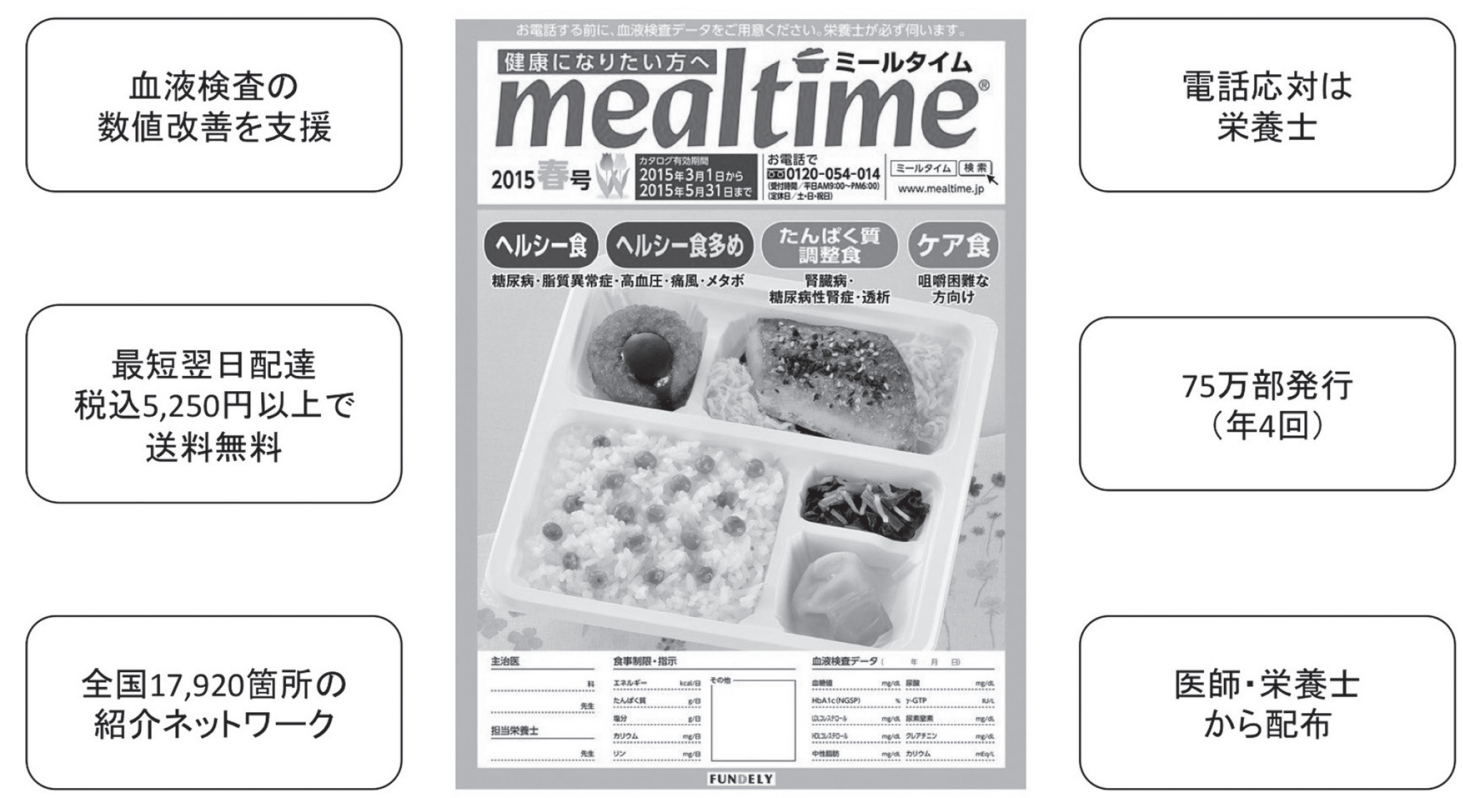




\section{6月}

ひよこ豆を使ってヘルシールヒ

カラフルピーマンのドライカレー
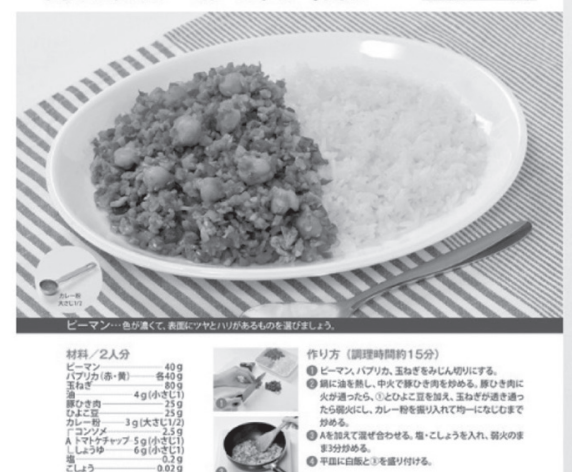

等,

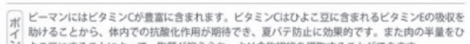

7

図表—13 カロリーマップ

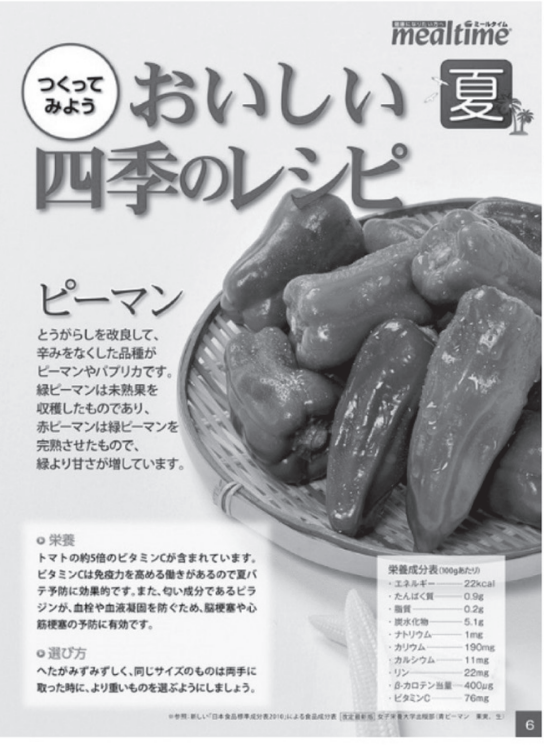

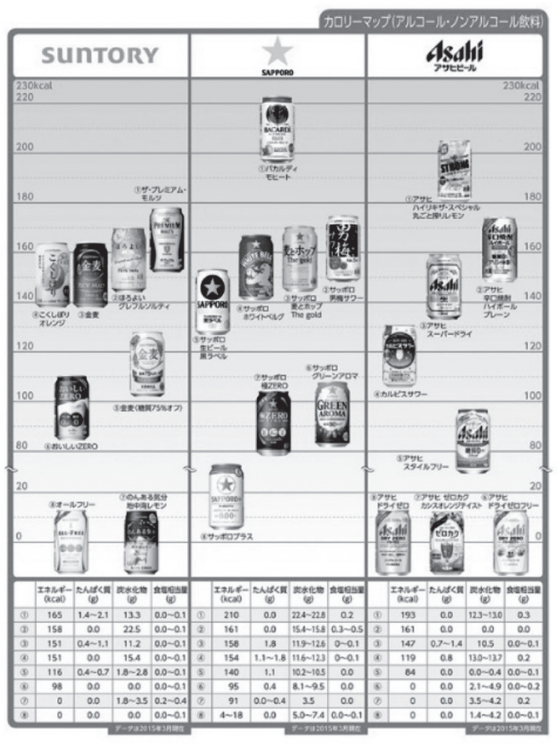

作は完全に広告費のみでまかなえるようになっ ている。

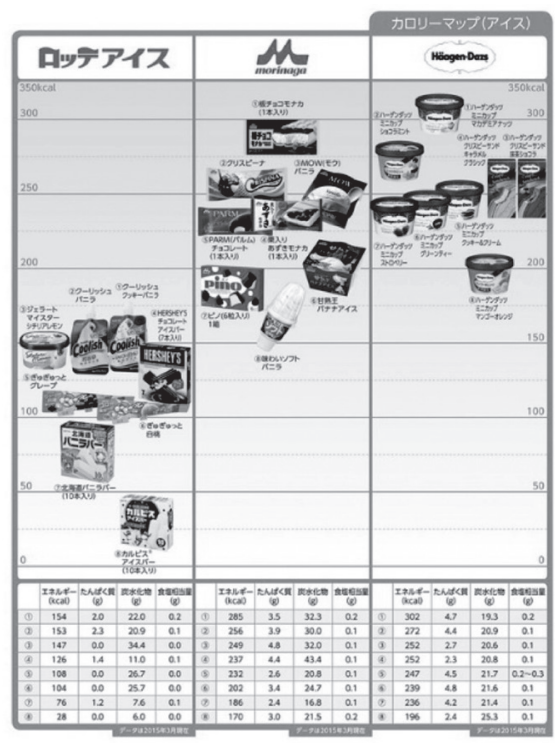

次に課題となったのが, カタログを潜在顧客 に対してどのように配布するのかということで 
あった。そこでまず先に, 医療機関のネット ワーク作りを考えた。このネットワーク作りで 活躍するのが, ファンデリーの栄養士たちであ る。そもそも, 栄養士とは, 栄養学に基づいて, 栄養のバランスの取れた献立作りや調理方法の 改善などを行う。よって, 栄養面から健康的な 食生活をコントロールしていくことを生業とす る。

一般的に栄養士は，官公庁・保健所・教育委 員会・病院・学校·工場・事業所・福祉施設・ スポーツ施設などでの栄養指導者として，また は, 大学・研究所・食品会社における研究員と して活躍するのが普通である。しかし，ファン デリーの栄養士たちは, 商品のメニュー開発や 顧客との健康相談といった栄養指導者という仕 事だけにとどまらず，カタログの製作や営業活 動といった仕事にも携わっている。

食の専門家である栄養士が作成したカタログ であるからこそ, カタログへの信頼が生まれる。 病院や介護施設, 調剂薬局へ栄養士がカタログ を活用してもらうための営業を行うからこそ, カタログへの信頼が担保され医療機関に置いて もらえる。

こうして栄養士の活躍によって作り上げた医 療機関とのネットワークを介して, 健康食通販 カタログ『ミールタイム』は顧客の手へと届け られるのである。

\section{VII. 信頼醸成の巧みさ}

以上、『ミールタイム』におけるファンデリー の取り組みを見てきたが，ここからどのような マーケティング上の示唆を得られるのであろう か?ここでは,「コンタクトポイント」という
枠組みで考えてみたい ${ }^{8)}$ 。

コンタクトポイントとは,「顧客がブランド に接するあらゆる場や瞬間」のことである。広 告, webサイト, クチコミ, 従業員, 実際の店 舗, 製品, 顧客サービス, 製品保証, IR 情報, CSR 活動など，というように顧客がブランドと 接した際の様々な接点を指す。それぞれのコン タクトポイントでは, ブランドとして一貫性の ある価值提供を示すものでなければならない。

現在, 消費者を取り巻くコンタクトポイント は複雑化し, 多様化している。また, ターゲッ トとコミュニケーションの目的を結ぶための導 線となるコミュニケーション・シナリオによっ て, 各コンタクトポイントで顧客に与える影響 の強さは異なる。ターゲットとのコミュニケー ションに拈いて, 有効なコンタクトポイントを 発見し, 有益なコミュニケーション・シナリオ を描くことが大切である。それぞれのコンタク トポイントにおいて，ターゲットに働きかける ことが出来る最適な結び目を抽出し，選択する ことが，コミュニケーション・シナリオを設計 する上で重要だ。本ケースの『ミールタイム』は, 顧客とブランドとの出会わせ方のコミュニケー ション・シナリオが, 他の宅配食サービス企業 と一線を画しているのである。

顧客とブランドとの結び目である川上部分の コンタクトポイントに抒いて，『ミールタイム』 は「信頼性」をキーワードとして顧客に肯定的 な選好を確立することに成功している。医療機 関への来院から『ミールタイム』の商品を注文 までの顧客の流れを見ていこう（図表-14）。

何らかの体調不良や健康診断の結果を受けて 医療機関にある患者さんが訪れたとしょう。そ の結果, 医師の診察や血液検査によって糖尿病 


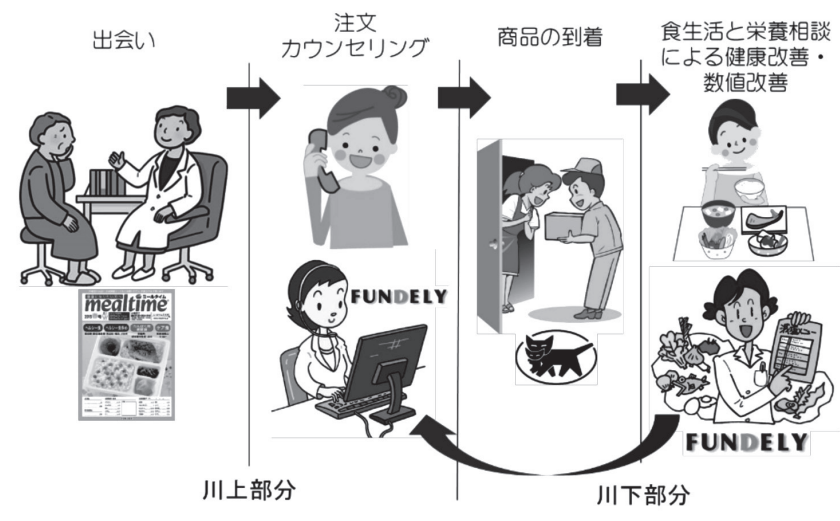

などの生活習慣病の疑いを診断されたとする。 医師は，食事療法として正しい食習慣の必要性 を具体的な摂取カロリー数や塩分量をあげて指 導する。医師の指導により事態の深刻さを悟っ た患者さんは，自分が患った病気に対して不安 を感じることであろう。また，栄養指導に沿っ た食事制限を患者さん自身の手で，それ通りに 行い, 続けていくことへの難しさに対しても不 安を感じるであろう。

この不安を感じている患者さんに医師が, そっと食事療法の参考にと『ミールタイム』を 差し出してくれるなら，患者さんは，医師への 信頼性をべースとして, 勧めてくれた『ミール タイム』に対してマイナスの感情を抱かないで あろう。これが顧客と『ミールタイム』の出会 いとなる。

次に, 自宅に帰り, 患者さんは『ミールタイ ム』に目を通す。そこには, ファンデリー商品 のカタログという面だけでなく, 四季のレシピ. 食品のカロリーマップというコンテンツや, 他 企業の商品広告などが載っている。医師の勧め
から『ミールタイム』への信頼性を担保してい る患者さんは, 商品への関心を示す。ファンデ リーに電話をかけてみると電話に出たのは栄養 士である。電話応対した栄養士は, 医師の診断 をべースとして食事制限のやり方や数值改善を 目的としたカウンセリングを行い，患者さんに 合った商品を紹介してくれた。この商品との出 会いの場でも栄養士のカウンセリングをベース として信頼性が釀成されていく。

このように, ファンデリーの信頼性を醸成さ せるためのコミュニケーション・シナリオは非 常に優れている。一般的に購入しょうと思った 製品やサービスの品質が分かりにくい場合，ま たは，製品やサービス間で差異を感じにくい場 合には，その製品やサービスの作り手である企 業への信頼度合が意思決定に影響を及ぼすこと が多い。例えば，テレビコマーシャルなどでの ベネフィットの際限のない羅列は, 多くの場合 で信頼性に欠けているために消費者に好意的な 印象を持たれないことであろう。これは，何ら かの信頼性が担保されていれば消費者に与える 
影響は変わってくるはずだ。

$$
\text { 『ミールタイム』のケースから上記の点につ }
$$
いて考えてみよう。栄養士は, 栄養学について 学んできているので, 食で人々を健康にしてい く専門家である。その栄養士が考案した健康食 なので商品に信頼性が生まれる。その商品を紹 介するカタログも栄養士が製作しているので信 頼性が担保され，医療機関に置いてもらえる。 医療機関では，そこに勤めている医師や栄養士 の手によって『ミールタイム』を患者さんに勧 めてくれる。医師や栄養士の推薦は, 患者さん の安心感につながる。しかし, そのカタログに ファンデリーの商品しか載せていなかったら信 頼してもらいにくいが, ファンデリーの取り組 みに賛同してくれた企業の広告があるので信頼 してもらえる。そして，カタログを見た患者さ んが, 注文の際に栄養士がカウンセリングして くれるので商品に対する信頼性が増す。

以上のように, 『ミールタイム』は信頼を醸 成させるコンタクトポイントの抽出と選択が非 常に優れている。各コンタクトポイントで生ま れた信頼の掛け合わせというコミュニケーショ ン・シナリオを描くことによって, 顧客の『ミー ルタイム』ブランドへの肯定的な選好を確立す ることに成功しているのである。

\section{VIII. ファンデリーの抱える課題}

前述したように，川上におけるコンタクトポ イントの選択とそのコミュニケーション・シナ リオは非常に優れている。しかし，川下におい てアキレス腱があるように思われる。それは, 商品を顧客に届ける最後のラストワンマイルで はないであろうか。
ファンデリーは, 独自の物流網を持っていな いので, 商品の配送をヤマト運輸に委託してい る。各コンタクトポイントでは, 顧客にブラン ドとして一貫性のある価值提供を行っていかな ければならない。しかし, 商品の配送がファン デリーから遠いところで行われているために, 『ミールタイム』ブランドの価值提供をコント ロールすることが難しい状態になっているので ある。

加えて, 栄養バランスの取れた食事を自宅ま で届けるというサービスは, 他の宅配食企業が 当然行っているサービスなので, ラストワンマ イルでの『ミールタイム』の差別性はなくなっ てしまう。一方で, ファンデリーでは『カウン セリングデリバリー』という栄養士が直接自宅 に商品を届けて, 同時にカウンセリングを行う サービスも提供している。現時点では, 届けら れる地域エリアやそのエリア内での顧客数, 配 送コストなどの問題が多いかもしれないが，今 後, 強化·改善していくべき課題の1つであろう。

また, 顧客の利便性という点も考えられる。 健康食・治療食という性質上, 続けて摄取しな ければ効果が得られないことは理解できる。し かし,「注文は7食以上から」という縛りは顧 客の自由な選択を制限してしまっているし，7 食以上となれば物理的にかなりのスペースを要 求されてしまう。それを冷凍保存出来るような 冷蔵庫を所有している家庭はそうそうないで あろう。かといって, 1食, 2 食のような少量 販売を行えば物流効率の問題が起きてしまい, 様々な面で顧客の負担が増えてしまう。このよ うに顧客の利便性も視野に入れるべき課題の 1 つであろう。 


\section{IX. 今後の展望}

最後に，ファンデリーに期待される今後の展 望を考えてみたい。

キーとなるのは，MFD事業で獲得した膨大 な顧客の医療データである。マーケティング事 業は，コンサルティング・ファームの様相を呈 しており，今後は栄養士の活躍により築き上げ た医療機関のネットワークと顧客企業とを結ぶ 場としてのプラットフォーム作りにヨリ注力し ていくことになるであろう。

ファンデリーがプラットフォームとして提供 できる価值は，顧客の健康診断の結果や血液 検査の数值などの医療デー夕の集約と提供で ある。例えば，健康に携わる顧客企業に対し て，ある特定のターゲットへのアプローチを行 いたい場合や，製品の共同開発などのコンサ ルティングを行う場合，プラットフォーマーで あるファンデリーは，ターゲットと顧客企業と のマッチングを行わなければならない。その際 に必要となるのがマッチングの精度である。こ れは医療データの蓄積と管理によって，精度を 高めていくことが出来る。しかし，マッチング の精度は一度築き上げてしまえば終わりという ものではないので，新たなマッチングの軸を追 加したり，ヨリ使いやすい機能を付け加えるな どの工夫が必要となるであろう。患者の変遷し ていく健康数值やそれに伴うニーズ，価值観な どの変化に合わせてマッチングの為に必要な情 報は変わっていく。ファンデリーには，プラッ トフォーマーとして提供する価值を具現化し続 け，ヘルスケアのコンサルティングファームと して展開していくことが望まれる。
ファンデリーは, 今後も多くの医療機関や健 康に携わる企業とアライアンスを組むことで, それぞれの蓄積された情報やノウハウ，顧客な どを取り达み，ヘルスケア総合企業としてのビ ジネスを構築していくであろう。そして，その 先には，阿部社長の掲げる「一食二医」社会の 実現が待っている。

謝辞

本ケースを作成するにあたり，株式会社ファ ンデリー・代表取締役の阿部公祐氏, 経営企画 室課長の茅野智憲氏，マーケティング事業部課 長の駒林真理子氏には貴重な時間を頂戴しイン タビューへの協力と原稿の確認をしていただい た。ここに記して感謝を申し上げたい。

\section{注}

1）我が国の健康に関する施策は，戦後，感染症対策を 中心に衛生水準を向上させることを目標として始 まった。この施策によって健康環境の改善が整うと, 徐々に疾病の予防や健康維持・増進にも重点が置か れるようになっていく。2011 年の「厚生労働白書」 によると, 終戦直後の 1947 年当時の死因ベスト 3 が『結核・肺炎・脳卒中』であり結核や肺炎のよう な感染症の病が多数を占めていた。ところが 1961 年を境として『脳卒中・癌 - 心臓病』となり死因構 造の転換が見られ，2010年時点では『癌・心臟病・ 脳卒中』となっている。心臟病や脳卒中は血管の異 常に由来する病であるので, 疾病構造が急性疾患か ら慢性疾患へと変化したことを読み取れる。

2）糖尿病は, インスリンの分泌量不足によってその働 きが悪くなり，細胞に栄養が取り込まれないことで, 血液中のブドゥ糖量が増加していく病気である。こ れにより高血糖の状態が続くと、いわゆる「血液が ドロドロ」な状態になり，血流が悪化し毛細血管が 詰まる。腎臟には糸球体という老廃物をろ過する毛 細血管の固まりがあるので，うまく老廃物をろ過す ることができなくなり，腎臟病となる。腎症が進む につれ尿を作る機能が低下し, 最終的には人工透析 によって腎臟の機能を代行しなければ生きていけな くなってしまう。 
3） 2011 年の「患者調査」によると, 1970 年代以降に 65 歳以上の高齢者の医療機関への受療率が急上昇し ている。加えて, 要介護認定者数は増加傾向にあり, 特に, 要支援と要介護度 1,2 といわれる, 軽度か ら中程度の方の増加率が高くなっている。これに よって, 老人医療を中心として医療費は増加基調に ある。

4) 栄養士は, 厚生労働大臣の指定した栄養士養成施設 (2 年以上）を卒業した後, 都道府県知事より免許を受 ける。一方で管理栄養士は, 国家試験によって免許 を受ける。よって管理栄養士は, 栄養士よりさらに 高度な知識と技術を修得した人といえる。栄養士は 主に健康な人々の給食管理に関わっているのに対し て，管理栄養士は個人を対象に病状や体質など様々 な要素を考慮した栄養指導や給食管理を行う。特に 大きな違いは，栄養指導ができるかできないかであ る。病院や老人ホームなどでの施設給食では, 栄養 面だけでなく医学や臨床面の見地からヨリ高度な専 門知識が望まれ，管理栄養士が行った栄養指導のみ 指導料として報酬を得ることができる。生活習慣病 や高齢社会が進む中，健康管理の重要性がますます 大きくなっているので, 栄養士と管理栄養士の必要 性はヨリ大きくなっていくことであろう。

5）ここでいう「中食」とは，スーパーなどの食料品店 で食材を購入してきて家庭内で調理し，その料理を 食するタイプの「内食」と, レストラン・ホテルな どのフードサービス店へ出かけていき, 注文した料 理を食する夕イプの「外食」との中間に属する食の スタイルのことを指す。具体的には, スーパー・コ ンビニ・デパ地下などで購入してきたり, 電話・イ ンターネットなどで注文して届けられた「扮菜・ お弁当・ピザ」などを, 家庭内・職場・学校等で調 理しないでそのまま食べることが出来る調理済みの 食品のことをいう。

6）我が国において，宅配食は，牛乳・調味料・お酒な どの家庭向けのビジネスとして浸透していった。現 在では，社会や消費者のライフスタイルの変化に合 わせて, サービス形態・対象商品も変化している。 宅配食市場は, 都市部を中心に核家族世帯の増加, 女性の社会進出による共働き世帯の増加, 高齢者世 帯の増加に伴う配達ニーズの高まりから成長市場と なった。よって, 多くの企業参入がみられた。宅配 食への参入は，食に携わる企業であれば一見容易に 思われる。しかし，顧客に店舗まで足を運んでもら うような外食・中食業のビジネスモデルと大きく異 なる点がある。それは配送コストで，500 円～600 円がメインとなる宅配食で利益を出すことは容易で はない。
7）成熟市場とコモディティ化との間には深い関係があ るが, 全く同じ意味ではない。成熟市場とは市場が 成長しにくい状態を指すが，コモディティ化とは製 品の差別性を打ち出すことが難しい状態のことであ る。成熟市場でも, 差別化することは出来る。しかし, コモディティ化とは差別化が難しい状態であるので, 市場はまだまだ成長している場合や，成長しきって いる場合もある。

8）スコット・M. デイビスとマイケル・ダンは, その著 書「ブランド価值を高めるコンタクト・ポイント戦 略」(ダイヤモンド社, 2004 年) の中において, コ ンタクトポイントを(1)購買前コンタクトポイント, (2)購買時コンタクトポイント, (3)購買後コンタクト ポイント, (4)影響コンタクトポイント, の 4 つに分 類している。1つ目の「購買前コンタクトポイント」 は, 潜在顧客がある製品の購入を考えた際に絞られ た候補の中に当該ブランドを含めるのか否かを決定 するのに影響力を与える接点。2つ目の「購買時コ ンタクトポイント」は, 顧客を考慮集合の中から当 該ブランドの購入へと導く接点。3つ目の「購買後 コンタクトポイント」は, 当該ブランドの購入・利 用後にブランドとの継続的なお付き合いを促すため の接点。4つ目の「影響コンタクトポイント」は, 顧客やその他の利害関係者に対して, ブランドへの 印象を間接的に植えつける働きのある接点のことで ある。

\section{中津 光広 (なかつ みつひろ)}

学習院大学大学院 経営学研究科 研究生。2009 年, 学 習院大学大学院経営学研究科博士後期課程単位取得。 2010 年より現籍。

専門は, 医療・介護のマーケティング論。

\section{青木 幸弘（あおきゆきひろ）}

学習院大学 経済学部経営学科 教授。1983 年, 一橋 大学大学院商学研究科博士課程単位取得。同大学商 学部助手, 関西学院大学商学部助教授を経て, 1995 年より現職。

専門は, 消費者行動論およびブランド論。 